\title{
EFFECT OF ADDITION OF FENNEL (FOENICULUM VULGARE L.) ON THE QUALITY OF PROTEIN BREAD
}

\author{
Bouchra Sayed-Ahmad ${ }^{1,3, \#, ~ E v i t a ~ S t r a u m i ̄ t e ~}{ }^{2}$, Mārtinš̌ Šabovics², Zanda Krūma², \\ Othmane Merah ${ }^{1}$, Zeinab Saad ${ }^{3}$, Akram Hijazi ${ }^{3}$, and Thierry Talou ${ }^{1}$ \\ ${ }^{1}$ Laboratoire de Chimie Agro-industrielle, UMR 1010 INRA/INP-ENSIACET, Université Fédérale de Toulouse Midi-Pyrénées, \\ INP-ENSIACET, 4 allée Emile Monso, 31030, Toulouse, FRANCE \\ ${ }^{2}$ Faculty of Food Technology, Latvia University of Agriculture, 22 Rīgas Str., Jelgava LV-3001, LATVIA \\ ${ }^{3}$ Doctoral School of Science and Technology, Lebanese University, Campus Rafic Hariri, BP 5, Hadath-Beirut, LEBANON \\ \# Corresponding author: bouchra.sayed.ahmad@ hotmail.com
}

Communicated by Daina Kārklina

\begin{abstract}
Fennel (Foeniculum vulgare L.) is an aromatic plant belonging to Apiaceae family widely cultivated elsewhere for its strongly flavoured leaves and seeds. Fennel seeds are of particular interest as a rich source of both vegetable and essential oils with high amounts of valuable components. However, residual cakes after oil extraction were typically considered as byproducts, in the present framework, the potential added value of these cakes was studied. The aim of this study was to investigate the effect of addition of fennel cake and seeds to protein bread quality. In the current research, a single-screw extruder, which is a solvent-free technique, was used for fennel seed oil extraction. For the protein bread making, fennel seed and cake flour in concentrations from 1 to $6 \%$ were used. Moisture, colour $L^{*} a^{*} b^{*}$, hardness, total phenolic concentration, DPPH radical scavenging activity, and nutritional value of protein bread were determined. The addition of fennel cake and seeds had significant $(\mathrm{p}<0.05)$ effect on bread crumb colour and hardness attribute, whereby the bread became darker and harder in texture than the control. Moreover, higher antioxidant activity and total phenolic concentration were observed for both protein breads enriched with fennel cake and seed flour. The overall results showed that addition of fennel cake and seed had beneficial effects on phenolic concentration, antioxidant activity and quality of protein bread. This result suggests also that added value of fennel seeds oil by-products could be increased by their utilisation in bread production.
\end{abstract}

Key words: fennel, fennel cake, bread quality, total phenolic, radical scavenging activity.

\section{INTRODUCTION}

Bread is the main dietary source in many countries; however, wheat bread is the most popular due to its textural and sensory properties (Ngozi, 2014). Nowadays, consumers increasingly require foods with functional properties. To meet consumer health requirements, the use of functional ingredients in bread formulations is increasingly expanding in the bakery industry as part of bread nutritional improvement (Alam et al., 2013).

Thus, daily consumption of whole grain bread is recommended as a substitute to refined products due to richness of bread in functional ingredients such as fibre, phytochemicals, minerals, essential amino acids and soluble vitamins (Ndife et al., 2013). However, more additives should be supplemented to bread formulation in order to overcome the undesirable effects of whole wheat flour on the bread qual- ity, such as textural properties and bread volume (Karaoglu and Boz, 2013); vital wheat gluten is a wheat protein isolate used as an additive to increase dough and bread yield, also to improve mixing tolerance and bread crumb texture, while additionally promoting the protein level and hence the nutritional value of the product (Constandache, 2005; Gianno and Tzia, 2016).

Fennel (Foeniculum vulgare Mill.) is an aromatic plant belonging to the Apiaceae family, and it is considered as one of the oldest medicinal plant cultivated throughout the world (Rather et al., 2012). Fennel seeds have particular economic importance, as they are widely used in the pharmaceutical, food, cosmetic, and healthcare industries. Fennel seeds are also a rich source of dietary fibre, proteins, vitamins, sterols and phenolic compounds (Kooti et al., 2015), as well as of both fixed and essential oil with high amounts of valuable components (80\% petroselinic acid and 
$70 \%$ trans-anethole, respectively) (Weiping and Bookang, 2011; Moghtader, 2013).

Large amounts of residual cake remain as waste products after fennel oilseed extraction. Recently there has been an increasing demand of exploitation of crops residues as a source of high-valuable molecules and antioxidant compounds, and thus these by-products could be utilized as valuable raw materials for functional food production (Saavedra et al., 2015). Nevertheless, in order to be competitive and capture bakery markets, an environmental friendly fennel seed extraction process should be established. The mono-screw pressing technique has been proposed as an ideal alternative to conventional techniques, as it is a solvent-free technique matching the green extraction principles by producing co-products instead of waste (Wahidu et al., 2014).

The aim of this study was to investigate the effect of addition of fennel cake and seed to protein bread (with added vital wheat gluten) quality.

\section{MATERIALS AND METHODS}

Fennel seed extraction. Extrusion was done by a Singlescrew (Model OMEGA 20, France) press with the following parameters: a $0.75 \mathrm{~kW}$ motor $(230 \mathrm{~V}, 5.1 \mathrm{~A})$, screw length $18 \mathrm{~cm}$, pitch screw $1.8 \mathrm{~cm}$, internal diameter $1.4 \mathrm{~cm}$, channel depth $0.5 \mathrm{~cm}$, and sleeve $2.5 \mathrm{~cm}$ internal diameter, and equipped with a filter-pierced outlet for liquid at the end of the screw and at the surface of the nozzles. The filter section to separate extracted oil had diameter $2 \mathrm{~mm}$. The feed rate and the screw rotation speed were maintained constant at $15 \mathrm{~g} \mathrm{~min}-1$ (0.9 $\left.\mathrm{kg} \cdot \mathrm{h}^{-1}\right)$ and $40 \mathrm{rpm}$, respectively. The nozzle diameter used in the pressing of fennel seed was 5 $\mathrm{mm}$. The nozzle/screw distance was $3 \mathrm{~cm}$. The screw press was first run for 15 min without seed material, but with heating via an electrical resistance-heating ring attached around the press barrel, to raise the screw press barrel temperature to the desired value. Fennel cakes obtained as byproducts by the extrusion process were used for further research.

Raw materials for protein bread preparation. Whole wheat flour (JSC Rīgas Dzirnavnieks, Latvia), wheat protein isolate Arise 5000 ( $\mathrm{GmbH}$ Lorima, Germany), sugar (Nordzucker GmbH \& Co, Germany), salt, dry yeast (S. I. Lesaffre, France) were procured from the local market of Jelgava, Latvia; while fennel seeds (Foeniculum vulgare Mill. var. dulce) were purchased from the local market of Toulouse, France.

Protein bread making technology. To determine the influence of fennel seeds and fennel cakes on protein bread quality and chemical composition, fennel seeds or fennel cakes was added at $2 \%, 4 \%$, and $6 \%$ of whole wheat flour amount. All ingredients were mixed for $5 \pm 1 \mathrm{~min}$ at a minimum speed using a dough mixer BEAR Varimixe (Wodschow \& Co, Denmark). Dough samples were fermented for
25 min at $36 \pm 2{ }^{\circ} \mathrm{C}$ temperature. Bread samples were then baked at $200 \pm 5{ }^{\circ} \mathrm{C}$ temperature for $20 \mathrm{~min}$ in a rotating convection oven (Sveba Dahlen, Sweeden) and then cooled at room temperature $22 \pm 2{ }^{\circ} \mathrm{C}$ for $2 \mathrm{~h}$.

In this paper, the following abbreviations of the samples are used:

- C - Protein bread without fennel flour

- FS2 - protein bread with $2 \%$ of fennel seed

- FS4 - protein bread with $4 \%$ of fennel seed

- FS6 - protein bread with $6 \%$ of fennel seed

- FC2 - protein bread with $2 \%$ of fennel cake

- FC4 - protein bread with $4 \%$ of fennel cake

- FC6 - protein bread with $6 \%$ of fennel cake

Protein bread moisture. The moisture of protein bread was determined using standard method ISO 712:2009. Measurements were made in triplicate.

Protein bread crumb hardness. Protein bread hardness was tested on the day of baking, at least $2 \mathrm{~h}$ after baking. Hardness of experimental bread samples was measured using a TA-XT plus Texture Analyser (Stable Micro Systems Ltd., Surrey, UK) with the following parameters: probe $25 \mathrm{~mm}$ diameter aluminium cylinder; test speed $-1 \mathrm{~mm}$ $\mathrm{s}^{-1}$; trigger force $-0.049 \mathrm{~N}$ and distance $-4 \mathrm{~mm}$ to the bread slice. All values are given as average of six measurements.

Protein bread crumb colour. To measure the colour of bread samples a Colour Tec-PCM/PSM (Accuracy Microsensors Inc., USA) was used based on the CIE L*a*b* colour system: $L^{*} 0=$ black, $100=$ white; $a^{*}+$ value $=$ red, value $=$ green $; b^{*}+$ value $=$ yellow,- value $=$ blue. Colour was measured at five different points within the crumb region; mean values were reported for each sample.

The total colour difference $(\Delta \mathrm{E})$ was defined by the Minolta equations $(1,2)$ :

$\Delta L=\left(L-L_{0}\right) ; \Delta a=\left(a-a_{0}\right) ; \Delta b=\left(b-b_{0}\right) ;$

$\Delta E=\sqrt{\Delta L^{2}+\Delta a^{2}+\Delta b^{2}}$

where

$L, a$ and $b-$ measured values of protein bread samples with fennel seed or cake;

$L_{0}, a_{0}$ and $b_{0}$ - values of the protein bread (control).

Extraction of phenolic compounds from protein bread. $1 \mathrm{~g}$ of protein bread was extracted with ethanol / acetone / water $(7 / 7 / 6 \mathrm{v} / \mathrm{v} / \mathrm{v})$ solution in an ultrasonic bath YJ5120-1 (Oubo Dental, USA) at $35 \mathrm{KHz}$ for $10 \mathrm{~min}$ at $20 \pm 1$ temperature. The mixture was then centrifuged in a centrifuge CM-6MT (Elmi Ltd., Latvia) at $3500^{-1}$ for $5 \mathrm{~min}$. 
Residual bread was then re-extracted with the same procedure and supernatant was combined. A triplicate extraction process was done for each sample.

Determination of total phenolic concentration (TPC). The TPC of the protein bread extract was determined by the Folin-Ciocalteu method (Singleton et al., 1999) with some modifications. $0.5 \mathrm{~mL}$ of extract was mixed with $2.5 \mathrm{~mL}$ Folin-Ciocalteu reagent (diluted 10 times with water); 3 min later, $2 \mathrm{~mL}$ sodium carbonate $\left(\mathrm{Na}_{2} \mathrm{CO}_{3}\right)\left(75 \mathrm{~g} \cdot \mathrm{L}^{-1}\right)$ was added and mixed. The mixture was allowed to stand for a further $30 \mathrm{~min}$ in the dark at room temperature, and absorbance was measured at $765 \mathrm{~nm}$. The TPC was calculated from the calibration curve of Gallic acid, and the results were expressed as Gallic acid equivalents (GAE) $100 \mathrm{~g}^{-1}$ dry weight (DW) of the samples.

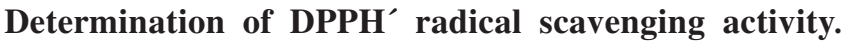
Antioxidant activity of the extract was measured using the 2.2-diphenyl-1- picrylhydraziyl DPPH method (Yu et al., 2003) with slight modifications. A solution of DPPH was freshly prepared by dissolving $4 \mathrm{mg}$ DPPH in $100 \mathrm{~mL}$ methanol. 0.5 of extract was added into a sample cavity containing $3.5 \mathrm{~mL}$ of DPPH solution. The mixture was then incubated in the dark for $30 \mathrm{~min}$ at room temperature. The absorbance was measured at $517 \mathrm{~nm}$ using a UV-VIS spectrophotometer JENWAY 6300. The radical scavenging activity was expressed as Trolox mM equivalents (TE) $100 \mathrm{~g}^{-1}$ dry weight (DW) of the samples.

Theoretical calculation of protein bread nutritional value. Nutritional value of protein bread was calculated using conversion factors according to EU Regulation No. $1169 / 2011$ on the provision off food information to consumers:

- carbohydrates (except polyols) $17 \mathrm{KJ} \mathrm{g}^{-1}-4 \mathrm{kcal} \cdot \mathrm{g}^{-1}$;

- protein, $17 \mathrm{KJ} \mathrm{g}^{-1}-4 \mathrm{kcal} \cdot \mathrm{g}^{-1}$;

- fat, $37 \mathrm{KJ} \mathrm{g}^{-1}-9 \mathrm{kcal} \cdot \mathrm{g}^{-1}$;

- fibre, $8 \mathrm{KJ} \mathrm{g}^{-1}-2 \mathrm{kcal} \cdot \mathrm{g}^{-1}$.

Statistical analysis. Means and standard deviations were determined. The data were subjected to one way analysis of variance (ANOVA). Significance was defined at $p<0.05$.

\section{RESULTS}

Protein bread moisture. Figure 1 shows the moisture (\%) of tested protein bread samples. The moisture of the control sample was $44.99 \pm 0.23 \%$. The moisture ranged from $50.30 \pm 0.09 \%$ (FC2) to $50.85 \pm 1.15 \%$ (FC6) in samples fortified with fennel cake, and from $48.23 \pm 0.92 \%$ (FS2) to $49.11 \pm 0.43 \%$ (FS6) in samples fortified with fennel seed.

Protein bread hardness analysis. Hardness of protein bread with fennel seeds and cakes analysis is shown in Figure 2. Hardness of the control sample was $1.27 \pm 0.13 \mathrm{~N}$, while in bread fortified with fennel cake, hardness ranged

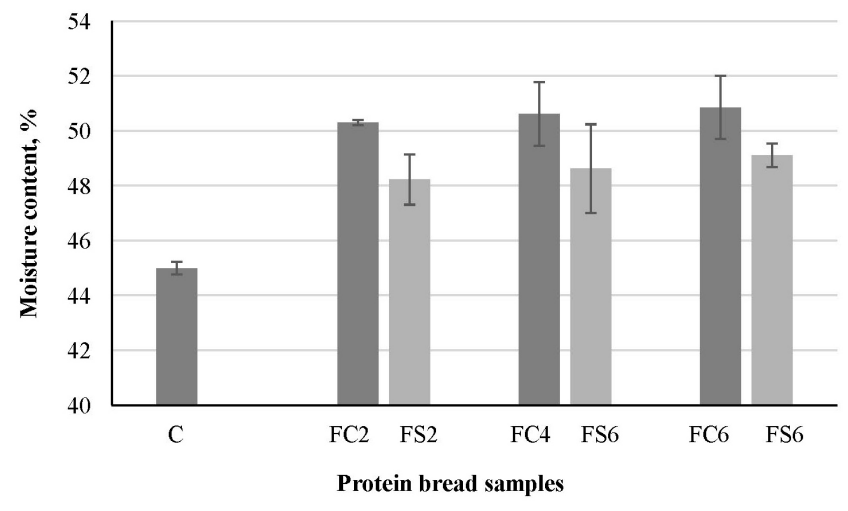

Fig. 1. Moisture of protein bread with fennel seeds and cakes.

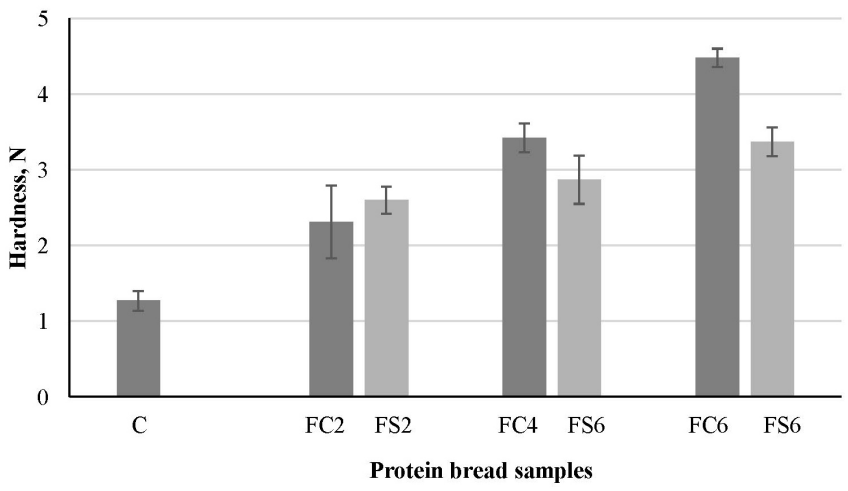

Fig. 2. Crumb hardness of protein bread with fennel seeds (FS) and fennel cakes (FC).

Table 1

THE COLOUR OF PROTEIN BREAD WITH FENNEL SEED (FS) AND FENNEL CAKE (FC)

\begin{tabular}{c|ccc}
\hline Bread samples & $\mathrm{L}^{*}$ & $\mathrm{a}^{*}$ & $\mathrm{~b}^{*}$ \\
\hline C & $61.08^{\mathrm{a}} \pm 2.06$ & $0.47^{\mathrm{d}} \pm 0.69$ & $20.32^{\mathrm{a}} \pm 1.96$ \\
FC2 & $54.81^{\mathrm{c}} \pm 0.68$ & $2.24^{\mathrm{cb}} \pm 0.76$ & $18.07^{\mathrm{ab}} \pm 1.53$ \\
FC4 & $51.88^{\mathrm{d}} \pm 1.59$ & $2.99^{\mathrm{ab}} \pm 0.66$ & $16.78^{\mathrm{ab}} \pm 3.04$ \\
FC6 & $50.45^{\mathrm{d}} \pm 0.85$ & $3.54^{\mathrm{a}} \pm 0.71$ & $18.80^{\mathrm{ab}} \pm 2.85$ \\
FS2 & $52.99^{\mathrm{bc}} \pm 1.75$ & $2.64^{\mathrm{cd}} \pm 0.27$ & $16.42^{\mathrm{b}} \pm 0.79$ \\
FS4 & $50.97^{\mathrm{c}} \pm 1.03$ & $4.50^{\mathrm{b}} \pm 0.43$ & $17.00^{\mathrm{ab}} \pm 2.81$ \\
FS6 & $49.99^{\mathrm{d}} \pm 1.34$ & $3.75^{\mathrm{b}} \pm 1.15$ & $16.18^{\mathrm{b}} \pm 1.76$
\end{tabular}

*Values marked with the same subscript letters in columns are not significantly different $(p>0.05)$. L, whiteness; a, redness; b, yellowness.

from $2.31 \pm 0.48 \mathrm{~N}$ (FC2) to $4.48 \pm 0.12 \mathrm{~N}$ (FC6) and from $2.60 \pm 0.18 \mathrm{~N}$ (FS2) to $3.37 \pm 0.19 \mathrm{~N}$ (FS6) in bread fortified with fennel seed.

Values of measured whiteness (L), redness (a) and yellowness (b) for bread with different ratios of added fennel cake and seed flour are shown in Table 1 . The values of $\mathrm{L}$, a and $\mathrm{b}$ in the control bread were $61.08 \pm 2.06,0.47 \pm 0.69$, and $20.32 \pm 1.96$, respectively. In the case of bread fortified with fennel cake, the range in $\mathrm{L}$ value was from $54.81 \pm$ 0.68 (FC2) to $50.54 \pm 0.85$ (FC6), a values from $2.24 \pm 0.76$ (FC2) to $3.54 \pm 0.71$ (FC6) and b values from $18.07 \pm 1.53$ (FC2) to $18.80 \pm 2.85$ (FC6); while for bread fortified with fennel seed, L values varied from $52.99 \pm 1.75$ (FS2) to 
$49.99 \pm 1.34$ (FS6), a values from $2.64 \pm 0.27$ (FS2) to 3.75 \pm 1.15 (FS6) and b values from $16.42 \pm 0.79$ (FS2) to 16.18 $\pm 1.76($ FS6)

Values of total colour difference $(\Delta \mathrm{E})$ are shown in Figure 3. $\Delta \mathrm{E}$ values ranged from 6.88 to 11.16 in bread with fennel cake (FC) and from 9.24 to 12.28 in bread with fennel seed (FS).

Total phenolic concentration (TPC) analysis. The total phenolic concentrations (TPC) expressed as Gallic acid equivalents (GAE) $100 \mathrm{~g}^{-1}$ dry weight (DW) of bread samples are given in Figure 4. TPC of the control sample was $113.73 \pm 1.4 \mathrm{mg} \mathrm{GAE} 100 \mathrm{~g}^{-1} \mathrm{DW}$ (range $148.95 \pm 4.15$ for FC2 to $187.49 \pm 6.38 \mathrm{mg} \mathrm{GAE} 100 \mathrm{~g}^{-1}$ DW for FC6) in the bread samples with fennel cake and from $167.96 \pm 3.27$ (FS2) to $196.05 \pm 0.01 \mathrm{mg} \mathrm{GAE} 100 \mathrm{~g}^{-1} \mathrm{DW}$ (FS6) in bread samples with fennel seed.

Radical scavenging activity analysis. DPPH radical scavenging activity of bread samples is shown in Figure 5. The values are expressed as Trolox mM equivalents (TE) 100 $\mathrm{g}^{-1} \mathrm{DW}$ of the samples. Radical scavenging activity of control bread was $6.300 .15 \mathrm{mM}$ TE $100 \mathrm{~g}^{-1} \mathrm{DW}$. DPPH radical scavenging activity had a range between $6.47 \pm 0.2$ and $7.68 \pm 0.19 \mathrm{mM}$ TE $100 \mathrm{~g}^{-1} \mathrm{DW}$ in bread enriched with 2 and $6 \%$ of fennel cake, respectively, and between $7.92 \pm$ 0.15 and $9.54 \pm 0.17 \mathrm{mM}$ TE $100 \mathrm{~g}^{-1}$ DW in bread enriched with 2 and $6 \%$ of fennel seed, respectively.

Nutritional values of protein bread. Nutritional and energy values of protein bread with fennel seed and cake were

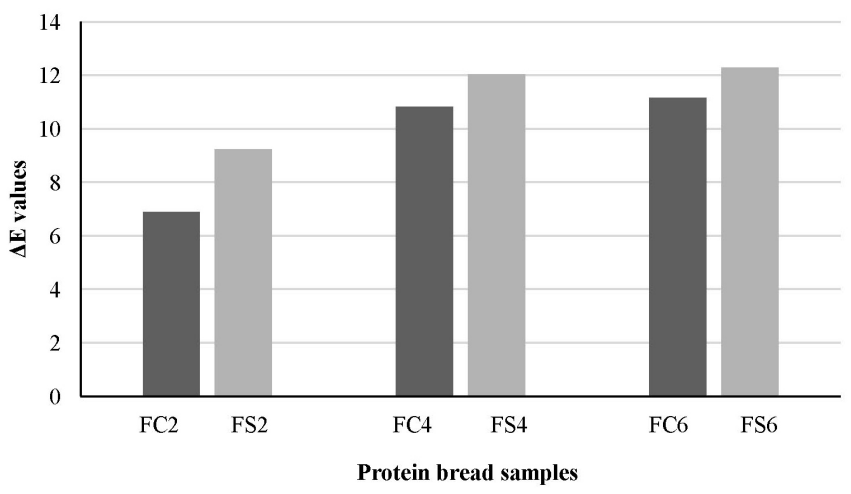

Fig. 3. Total colour difference $(\Delta \mathrm{E})$ of protein bread with fennel seeds $(\mathrm{FS})$ and fennel cakes (FC).

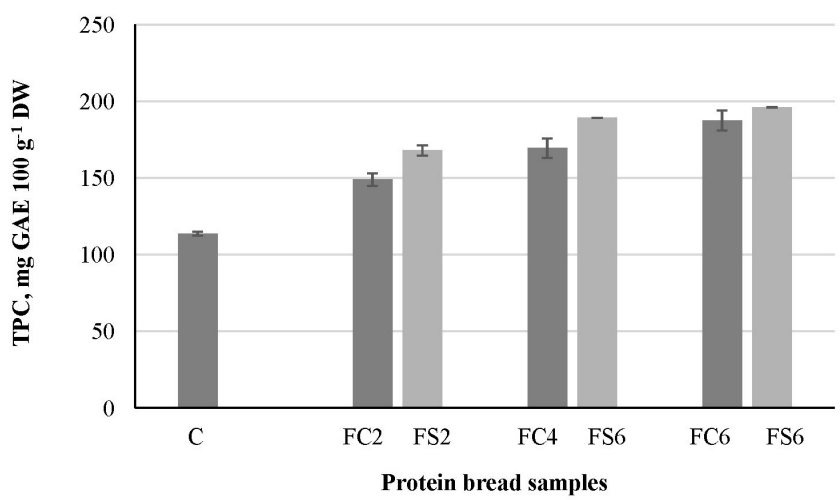

Fig. 4. Total phenolic concentration (TPC) in the protein bread samples.

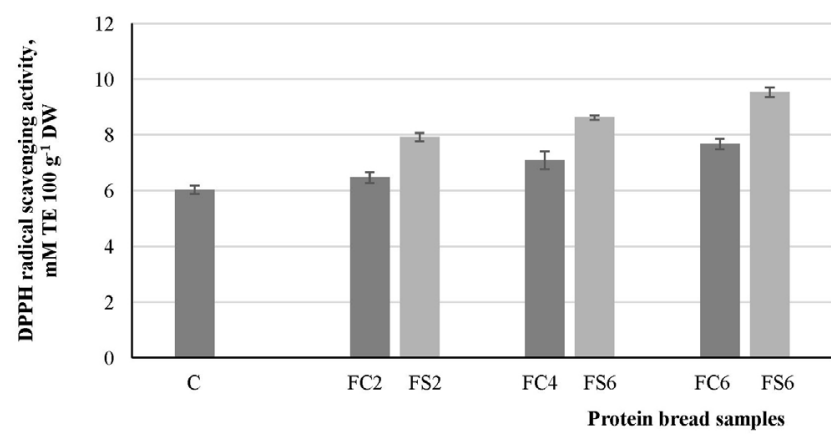

Fig. 5. DPPH radical scavenging activity of protein bread samples.

Table 2

CALCULATED NUTRITIONAL AND ENERGY VALUES OF DIFFERENT PROTEIN BREAD

\begin{tabular}{c|ccc|c|c|c}
\hline \multirow{2}{*}{$\begin{array}{c}\text { Bread } \\
\text { samples }\end{array}$} & \multicolumn{3}{c}{ Nutrients, g.100 g } & \multicolumn{2}{c}{$\begin{array}{c}\text { Energy value, } \\
100 \mathrm{~g}^{-1}\end{array}$} \\
\cline { 2 - 7 } & $\begin{array}{c}\text { Carbohy- } \\
\text { drates }\end{array}$ & Protein & Fat & Fibre & $\mathrm{kcal}$ & $\mathrm{kJ}$ \\
\hline C & 25.59 & 21.64 & 0.97 & 4.96 & 207.57 & 3614.00 \\
FC2 & 25.88 & 21.71 & 1.05 & 5.09 & 213.71 & 3638.04 \\
FC4 & 26.16 & 21.78 & 1.14 & 5.22 & 219.85 & 3662.08 \\
FC6 & 26.45 & 21.85 & 1.23 & 5.35 & 225.57 & 3686.12 \\
FS2 & 25.83 & 21.69 & 1.12 & 5.08 & 214.47 & 3643.02 \\
FS4 & 26.08 & 21.74 & 1.27 & 5.19 & 221.37 & 3668.04 \\
FS6 & 26.32 & 21.79 & 1.43 & 5.31 & 228.27 & 3695.06
\end{tabular}

calculated using conversion factors, and the results are illustrated in the Table 2. Composition of protein bread control was as follows: total carbohydrates $-25.59 \mathrm{~g} \cdot 100 \mathrm{~g} \mathrm{~g}^{-1}$, protein $-21.64 \mathrm{~g} \cdot 100 \mathrm{~g}^{-1}$, fat $-0.97 \mathrm{~g} \cdot 100 \mathrm{~g}^{-1}$, fibre -4.96 $\mathrm{g} \cdot 100 \mathrm{~g}^{-1}$, and energy value $3614.00 \mathrm{~kJ} / 207.57 \mathrm{kcal} \cdot 100$ $\mathrm{g}^{-1}$. The obtained results indicate that all the values increased with increasing levels of fennel flour substitutions (2, 4 and $6 \%$ ) except for fat concentration and energy value, which showed the reverse.

\section{DISCUSSION}

As can be seen in Figure 1, samples fortified with fennel seed flour had significantly higher $(p<0.05)$ moisture than the control sample: $44.99 \pm 0.23 \%$ in the control and 49.11 $\pm 0.43 \%$ in the sample with $6 \%$ fennel seed flour. Moisture was significantly $(p<0.05)$ higher in bread with fennel cake flour (Fig. 1) than in the control and in bread with fennel seed flour. Several studies reported higher moisture with increased substitution level (Das et al., 2013) (Olaoye and Onilude, 2011). The differences in moisture of protein bread samples might be due to inclusion of a greater amount of insoluble dietary fibre with fennel (Maneju et al., 2011). As a drawback, high moisture promotes microbial proliferation and thus it is linked with shorter shelf life of composite breads (Ndife et al., 2011).

Texture is a key quality parameter that consumers appreciate in bread. Bread crumb hardness was significantly affected $(p<0.05)$ by fennel seed and fennel cakes addition 
(Fig. 2). Hardness of bread increased with increasing amount of fennel cake flour in bread. A similar trend was observed for bread with fennel seed flour, but in this case significant differences were observed only between samples FS2 and FS6 fennel seed flour. Moreover, bread enriched with fennel cake flour had higher hardness than that enriched with fennel seed flour. These findings are in agreement with similar studies (Das et al., 2013), which reported that fennel seed addition increased the firmness of white bread. Hardness is mainly attributed to the solid / water ratio, the effect of added fennel powder on bread viscosity and increase of moisture in the composite bread (Amir et al., 2013; Giannou and Tzia, 2016).

The quality of final product is also highly affected by the bread crumb colour. The results showed that all fortified samples had significantly $(p<0.05)$ lower $\mathrm{L}$ and $\mathrm{b}$ than the control, indicating darker colour (Table 1). Moreover, a values indicated that the formulas prepared with different levels of fennel were more brown then those of the control sample. This increase in a values can be attributed to the light brown colouration of fennel cakes and seed. The same trend was observed for $\mathrm{L}$ values of white bread fortified with fennel seed, which can be explained by the difference in the initial flour type used (Das et al., 2013).

Regarding the total colour difference ( $\Delta \mathrm{E}$ ) (Fig. 3), bread fortified with fennel seed showed higher $\Delta \mathrm{E}$ values than bread with fennel cake, which may be due to the darker colour of fennel seed flour, as fennel seed powder is darker than fennel cake powder.

The results given in Figure 4 showed that TPC of bread in both cases increased with increase of fennel level. When fennel substitution was increased from 0 to $6 \%$, TPC of the bread increased from 113.73 to 187.49 and $196.05 \mathrm{mg}$ $\mathrm{GAE}^{-1} 100 \mathrm{~g}$ DW in bread with fennel cake and seed, respectively. Moreover, TPC of bread with fennel seed was higher than that with fennel cake at the same fennel level. Previous studies showed that oil extraction is usually accompanied with loss of some lipophilic phenolic compounds, which might explain the lower TPC of bread with defatted seeds (Yu et al., 2013). However, this is not a huge lost and almost all the phenolic compounds remain in the cake, which make it a rich source of phenolics and underline its added value in bread.

DPPH radical scavenging activity was significantly higher (Fig. 5) in bread enriched with 2-6\% fennel flour than in the control bread. The antioxidant activity of extract from enriched bread increased from 6.03 (control bread) to 7.67 and $9.54 \mathrm{mM}$ TE $100 \mathrm{~g}^{-1} \mathrm{DW}$ in bread with fennel cake and seed, respectively. The correlation coefficients between TPC and DPPH scavenging capacity for bread enriched with fennel cake and seed were 0.931 and 0.918 , respectively, which indicated a good linear relationship between TPC and DPPH radical scavenging capacity. The obtained results are comparable to literature (Das et al., 2013), which report that increasing level of fennel seeds (up to $7 \%$ of fennel seed powder) increases antioxidant capacity of bread.
Several studies showed also the negative impact of seed defatting on the antioxidant activity, which is attributed to the presence of vegetable oils, which generally are an important source of antioxidants (Brodowska et al., 2014).

As can be seen in the Table 3, an increase of fennel flour addition in produced protein bread leads to an increase of carbohydrate, protein and fibre concentration, and decrease of fat concentration. Moreover, bread enriched with fennel cake showed a slightly higher concentration of carbohydrate, protein and fibre than bread enriched with fennel seed, which was expected as similar results were obtained by El-Demery et al. (2015) in the case of bread fortified with full fat and semi-defatted flaxseed.

\section{CONCLUSION}

The obtained results showed that the addition of fennel cake flour in protein wheat bread imparted significant improvement in nutritional constituents, moisture and hardness, compared to bread enriched with fennel seed flour and to control bread. This work shows also that fortified bread is a good source of antioxidant compounds like polyphenols beneficial for human health and thus it can be recommended as functional food for the public who are really aware about their well-being. Therefore, fennel cake residues could be processed as co-product in value-added applications such as bread making.

\section{ACKNOWLEDGMENTS}

The authors acknowledge financial support from the project "Sustainable use of local agricultural resources for development of high nutritive value food products (Food)" within the National Research Programme "Sustainable use of local resources (earth, food, and transport) - new products and technologies (NatRes) (VPP2014-2017)”.

\section{REFERENCES}

Alam, J., Talukder, M. U., Rahman, M. N., Prodhan, U. K., Obidul Huq, A. K. (2013). Evaluation of the nutritional and sensory quality of functional breads prepared from whole wheat and soybean flour. Ann. Food Sci. Technol., 14 (2), 171-175.

Amir, I. Z., Hanida, H. S., Syafiq, A. (2013). Development and physical analysis of high fiber bread incorporated with cocoa (Theobroma cacao sp.) pod husk powder. Int. Food Res. J., 20 (3), 1301-1305.

Anonymous (1990). Official Methods of Analysis. 15 $5^{\text {th }}$ edn. Washington, DC. Association of Official Analytical Chemists.

Brodowska, K. (2014). A comparison of antioxidant properties of extracts from defatted and non-defatted flax (Linum usitatissimum) seeds. Albanian J. Agricult. Sci., 13 (2), 16-23.

Constandache, M. (2005). Effects of vegetal protein extracts to the quality of bread. Agroalimentary Proc. Technol., 6 (1), 79-84.

Das, L., Raychaudhuri, U., Chkraborty, R. (2013). Herbal fortification of bread with fennel seeds. Food Technol. Biotech., 51 (3), 434-440.

El-Demery, M., Mahmoud, K. F., Bareh, G. F., Albadawy, W. (2015). Effect of fortification by full fat and defatted flaxseed flour sensory properties of wheat bread and lipid profile laste. Int. J. Curr. Microbiol. App. Sci., 4 (4), 581-598. 
Giannou, V. Tzia, C., (2016). Addition of vital wheat gluten to enhance the quality characteristics of frozen dough products. Foods, 5 (6), 1-10.

Karaoglu, M. M., Boz, H., (2013). Improving the quality of whole wheat bread by using plant origin materials. Czech J. Food Sci., 31 (5), 457-466.

Kooti, W., Moradi, M., Ali-Akbari, S., Sharafi-Ahvazi, N., Asadi-Samani, M., Ashtary-Larky, D. (2015). Therapeutic and pharmacological potential of Foeniculum vulgare Mill: A review. J. Herb. Med. Pharmacol., 4 (1), $1-9$.

Maneju, H., Udobi, C. E., Ndife, J. (2011). Effect of added brewers dry grain on the physico-chemical, microbial and sensory quality of wheat. Amer. J. Food Nutr., 1(1), 31-43.

Moghtader, M. (2013). Chemical composition, antimicrobial and antioxidant from the seeds and flowers of Foeniculum vulgare Mill. from Kerman Province. J. Hortic. For., 5 (3), 37-40.

Ndife, J., Abdulraheem, L. O., Zakari, U. M. (2011). Evaluation of the nutritional and sensory quality of functional breads produced from whole wheat and soya bean flour blends. Afr. J. Food Sci., 5 (8), 466-472.

Ndife, J., Obiegbunna, J., Ajaya, S. (2013). Comparative evaluation of the nutritional and sensory quality of major commercial whole-wheat breads in Nigerian market. Adv. J. Food Sci. Technol., 5 (12), 1600-1605.

Ngozi, A. A. (2014). Effect of whole wheat flour on the quality of wheatbaked. Global J. Food Sci. Technol., 2 (3), 127-133.
Olaoye, O. A., Onilude, A. A. (2011). Microbiological, proximate analysis and sensory evaluation of baked products from blends of wheat/breadfruit flours. Afr. J. Food Agric. Nutr. Dev., 8, p. 1-12.

Rather, M., Dar, B. A., Sofi, S. N., Qurishi, M. A. (2016). Foeniculum vulgare: A comprehensive review of its traditional use, phytochemistry, pharmacology, and safety. Arabian J. Chem., 9 (Suppl. 2), 1574-1583.

Saavedra, M., Aires, A., Dias, C., Almeida, J. A., Vasconcelos, M. C. B. M. D., Santos, P., Rosa, E. A. (2015). Evaluation of the potential of squash pumpkin by-products (seeds and shell) as sources of antioxidant and bioactive compounds. J. Food Sci. Tech., 52 (2), 1008-1015.

Singleton, V. L., Ortofer, R., Lamyeal-Raventos, R. M. (1999). Analysis of total phenols and other oxidation substrates and antioxidants by means of Folin Ciocalteu Reagent. In: Packer, L. (Ed.). Methods in Enzymology. Academic Press, Orlando, pp. 152-178.

Wahidu, Z., Deli, S., Wan, N. W., Tajul, Y. A. (2014). Physicochemical and quality characteristics of cold and hot press of Nigella sativa L. seed oil using screw press. J. Appl. Sci. Res., 10 (12), 36-45.

Weiping, H., Bookang, H. (2011). A review of chemistry and bioactivities of a medicinal spice: Foeniculum vulgare. J. Med. Plants Res., 5 (16), 3539-3600.

Yu, L., Nanguet, A. L., Beta, T. (2013). Comparison of antioxidant properties of refined and whole wheat flour and bread. Antioxidants, 2, 370-383.

Yu, L., Perret, J., Wilson, J., Haley, S. (2003). Antioxidant properties of bran extracts from "Akron" wheat grown at different locations. J. Agric. Food Chem. 51, 1566-1570.

Received 19 October 2016

Accepted in the final form 18 October 2017

\section{FENHEL̨A (FOENICULUM VULGARE L.) IETEKME UZ OLBALTUMVIELU MAIZES KVALITĀTI}

Fenhelis (Foeniculum vulgare L.) ir aromātisks augs, kas pieder Apiaceae dzimtai. Fenheḷa sēklas ir bagātas ar aromātiskajām eḷāam. Pēc elḷas iegūšanas pārstrādes procesā rodas spiedpaliekas, kuras iespējams izmantot citos produktos. Tāpēc pētījuma mērkis bija pētīt fenhel̦a eḷlas spiedpalieku ietekmi uz olbaltumvielu maizes kvalitāti. Olbaltumvielu maizes gatavošanā fenheḷa sēklas un fenheḷa spiedpaliekas no eḷlas ražošanas pievienotas no $1 \%$ līdz $6 \%$. Maizes paraugiem analizēti sekojoši parametri — mitrums, krāsas izmaiņas, cietība, kopējais fenolu saturs un antiradikālā aktivitāte, kā arī aprēķināta maizes uzturvērtība. Fenheļa sēklu un spiedpalieku pievienošana būtiski ietekmē $(p<0.05)$ olbaltumvielu maizes mīkstuma krāsu un cietību, kā arī maizei ir paaugstināts kopējo fenolu saturs un antiradikālā aktivitāte. Iegūtie rezultāti parādīja, ka fenheḷa spiedpaliekas var izmantot olbaltumvielu maizes ražošanā, palielinot maizes bioloğisko vērtību. 